\title{
VÝSTAVA SLEZSKÉ ZÁMECKÉ KNIHOVNY NA ZÁMKU HRADEC NAD MORAVICÍ
}

\author{
Barbora Nebeská (Praha)
}

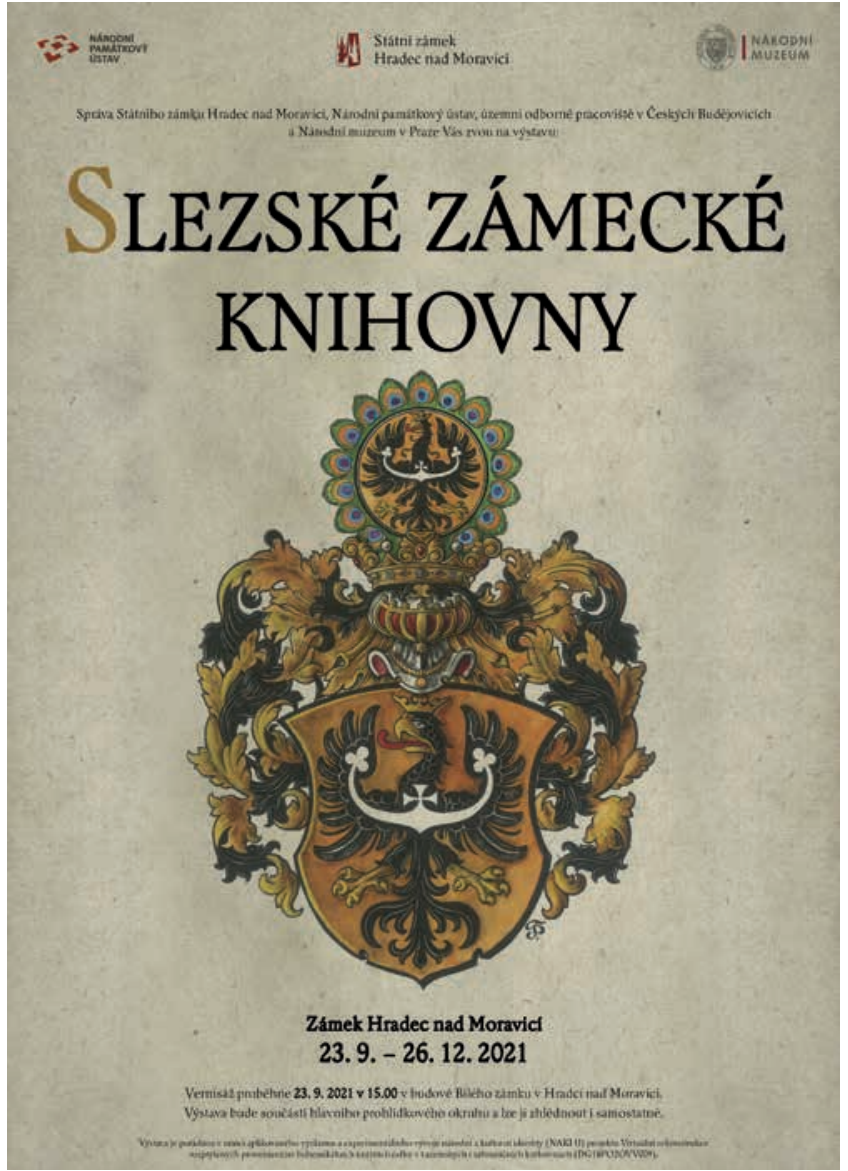

Obr. 1. Plakát k výstavě „Slezské zámecké knihovny“ s využitím kresby heraldika Petra Tybitancla.

„,Dalši zprávy o knihovně chybí. Zde stopy po knihovně končí. O obsahu knihovny nejsou žádné zprávy. Knihovna beze stop zmizela. “ To jsou věty, před které je velice často postaven badatel, který se rozhodne věnovat studiu slezských zámeckých knihoven. Nabízí se otázka, zda má vůbec cenu po takových fondech pátrat? Zda vynaložené úsilí není jen ztrátou času? Vrátíme-li se do května roku 1945, zastihneme zámecké objekty ve stavu naprostého zmatku. Po útěku či odsunu původních majitelů docházelo na zámcích $\mathrm{k}$ živelnému rabování, ale též ke stejně živelným pokusům o záchranu umělecky a historicky hodnotného majetku. Sled událostí tedy nelze v úplnosti věrně rekonstruovat. Informace o osudech

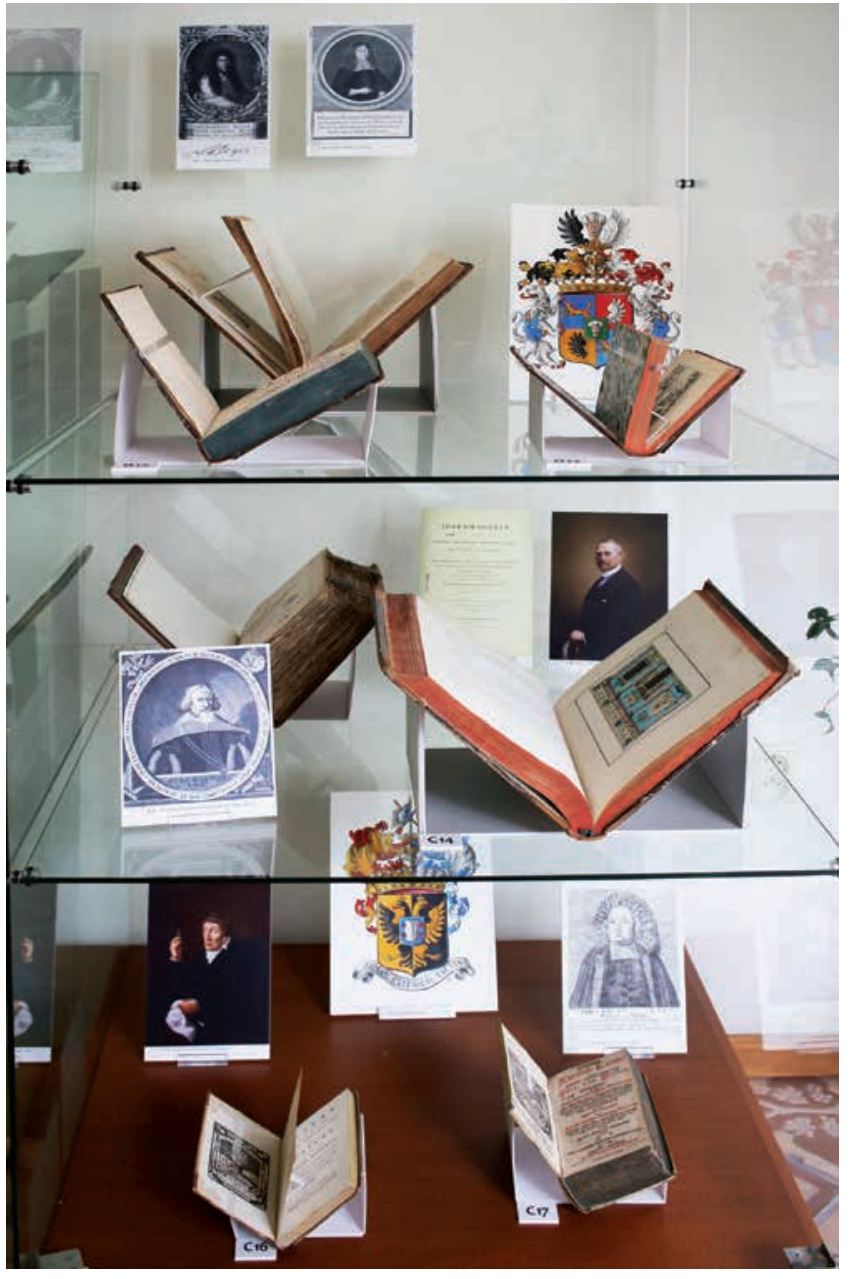

Obr. 2. Jedna z deseti vitrín s vystavenými tisky. Instalace byla obohacena o malované erby Petra Tybitancla a též o portréty autorů či samotných vlastníků knih.

slezských zámeckých knihoven jsou mnohdy kusé či zcela schází. Problematická je též orientace ve spleti organizační struktury institucí a komisí odpovědných za poválečnou péči o zámecké objekty, jejichž pravomoci se mnohdy překrývaly.

Celkem se na našem území dochovalo na 350 zámeckých knihoven. Ve srovnání s Moravou, kde se na více než 230 zámcích zachovalo přibližně 94 zámeckých knihoven, je počet přeživších slezských zámeckých knihoven, které se v relativní celistvosti dochovaly jen tři, zcela tristní. 


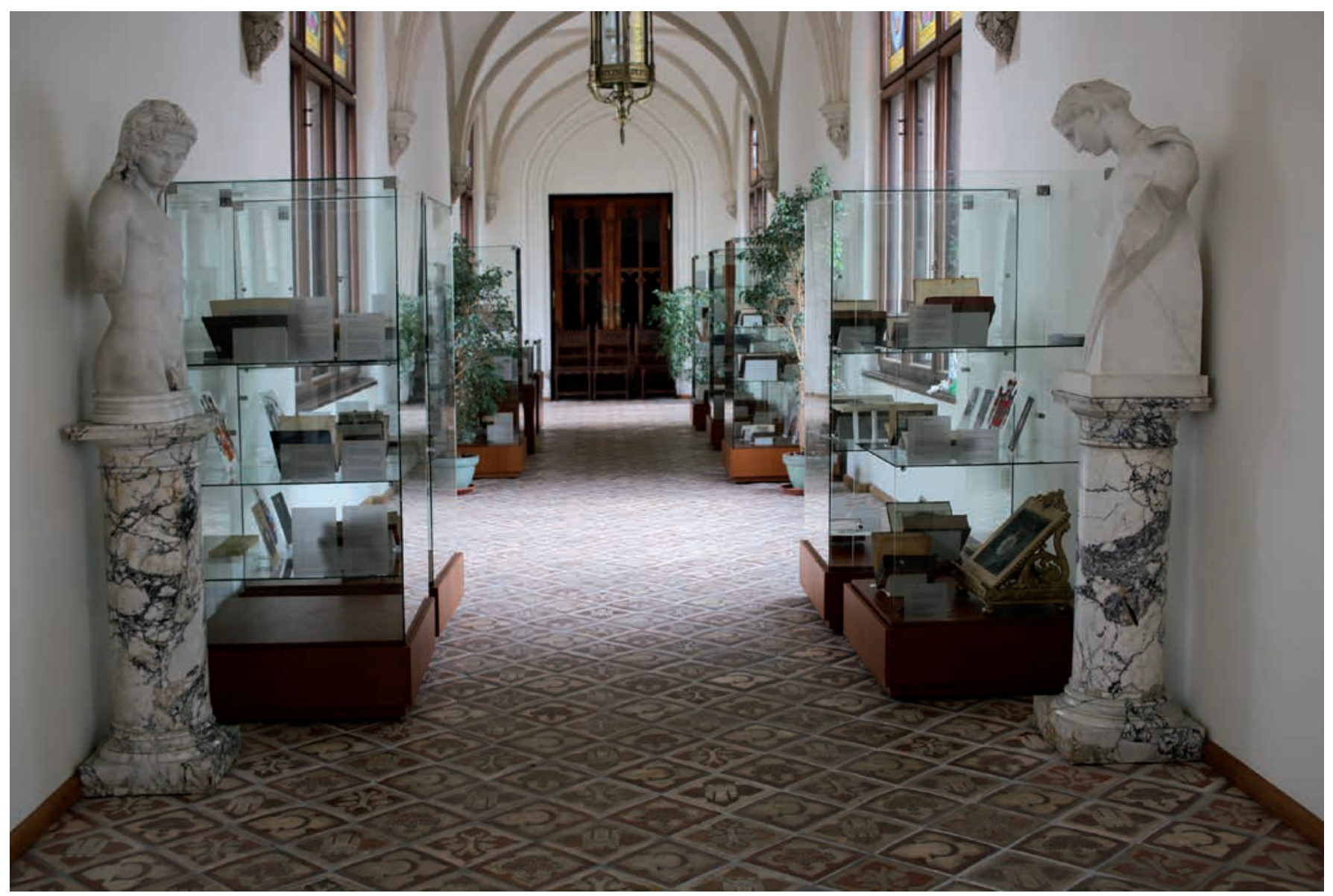

Obr. 3. Celkový pohled na výstavu.

Jako zásadní se jeví svěření slezských zámeckých knihoven Národní kulturní komisí do opatrovnictví místním vědeckým institucím. Dle Agendy Knihovny Národního muzea s fondy nejčastěji manipuloval Slezský studijní ústav, jehož původně vlastenecká ideologie byla nedlouho po válce vystřídána ideologií komunistickou. Mnoho knihoven z majetku „feudálních protektorů“1 tak bylo rozptýleno či rozprodáno $\mathrm{v}$ antikvariátech a $\mathrm{v}$ nejhorším případě i zlikvidováno.

Odpovědí na výše zmíněnou otázku, zda má cenu se těmto rozptýleným fondům věnovat, může být výstava, která proběhla v termínu od 23. září do 26. prosince 2021 na Státním zámku Hradec nad Moravicí, konkrétně v koridoru Bílého zámku, ve spolupráci Národního muzea a Národního památkového ústavu. Výstava byla pořádána díky projektu NAKI II Virtuální rekonstrukce rozptýlených provenienčně bohemikálních knižních celk ̊‥ Představeny byly staré tisky, ale též mladší produkce 19. a první poloviny 20. století. Ze tří dochovaných slezských zámeckých knihoven bylo vystaveno celkem 22 exemplářu z celkového počtu 50 instalovaných knih. Z Hradecké majorátní knihovny knížat Lichnowských byly vybrány dvě publikace s autorskými dedikacemi kněžně Mechtildě Lichnowské (1879-1958). Kněžna byla sama literárně činná. Tvořila $\mathrm{v}$ duchu expresionismu a věnovala se též kresbě. Do známého časopisu Die Fackel dramatika Karla Krause (1874-1936) přispívala svými karikaturami. Mezi jejími přáteli se objevovali významní spisovatelé a umělci své doby, z nichž mnohé hostila na zámku v Hradci nad Moravicí. Drama Der arme Heinrich (Berlín, 1902) jí věnoval nositel Nobelovy ceny za literaturu Gerhart Hauptmann (1862-1946), sbírku Die Sonette an Orpheus (Lipsko, 1923) získala od prozaika a básníka Rainera Marii Rilkeho (1875-1926). Největší slezská zámecká knihovna Bruntál byla reprezentována deseti tituly původně z majetku arcivévody Evžena Habsburského (1863-1954), velmistra řádu německých rytírù, vojevi̊dce, sběratele a znalce umění. Konkrétně šlo např́íklad o literárně teoretickou publikaci uměleckého kritika a dramaturga Hermanna Bahra (1863-1934) Expresionismus (Mnichov, 1916) či biografickou monografii členů habsburské monarchie Oesterreichs Kaiserhaus (Vídeň, 1877) z pera Alfreda Schönwalda. Za zapůjčení těchto knih je třeba poděkovat Muzeu v Bruntále. Třetí existující knihovnu Solca ${ }^{3}$ na výstavě zastupoval soubor alchymistických tisků původně z majetku Jana Josefa Larisch-Mönnich (1766-1820), Karla Františka hraběte Vetter z Lilie (1719-1792) a Josefa Ondřeje svobodného pána Bereczko-Rzeplynského (* 1730). Vlastnictví těchto

\footnotetext{
${ }^{1}$ ORLÍK, Josef. Počátky Gymnasijního muzea v Opavě. In: 150 let Slezského muzea. Opava: Krajské nakladatelství v Ostravě, 1964, s. 27.

${ }^{2}$ K výstavě vznikl též katalog Slezské zámecké knihovny (České Budějovice, 2021), z něhož text tohoto př́spěvku částečně vychází.

3 Budova zámku Solca byla zbořena roku 1953. Historická část fondu se v současné době nachází na nedalekém zámku Fryštát (Karviná).
} 


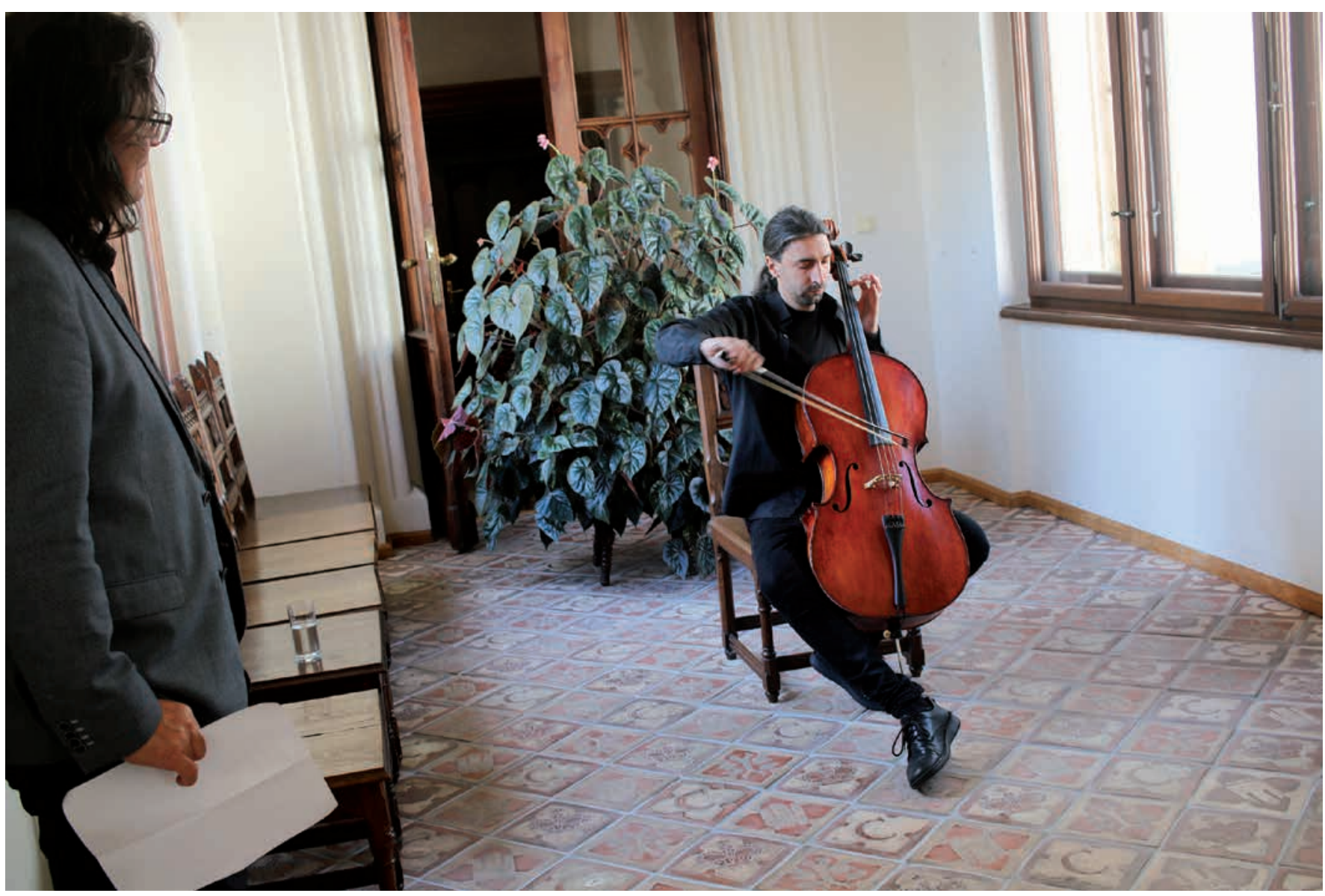

Obr. 4. Vernisáž proběhla 23. záŕí 2021 za hudebního doprovodu Jana Hanouska. Úvodního slova se ujal kastelán zámku Hradec nad Moravicí Ing. Radomír Přibyla.

knih dokládají heraldická exlibris zmíněných šlechticů. V případě hraběte Vettera z Lilie též rukopisný vpisek: „,Ex libris Caroli Josephi Comitis Vetter de Lilye“.

Vystavené exempláře $\mathrm{z}$ fondů, které během let utrpěly zásadní ztráty či se dochovaly v torzálním stavu, pocházely původně ze zámků Deštné, Dolní Životice, Dubová (Horní Vikštejn), Fulnek, Hošt’álkovy, Kobylá, Kyjovice, Paskov, Ropice, Stěbořice, Štáblovice, Třebovice a Velké Hoštice. $\mathrm{S}$ výjimkou Dubové a Stěbořic ${ }^{4}$ byly tyto tisky zapůjčeny z historického fondu knihovny Slezského zemského muzea v Opavě. Identifikovány byly na základě provenienčního průzkumu, který v knihovně proběhl roku 2020. Vysledován byl např́iklad soubor více než sta titulů opatřených vlastnickým vpiskem Josefa Václava hraběte z Wrbna a Freudenthalu (1738-1819), majitele Fulneku. Uchováno je zde též několik tisků s exlibris spisovatelky Marie Scholzové, rozené Stonawké (1861-1943), publikující pod pseudonymem Marie Stona, pro jejíž rezidenci v Třebovicích se vžil výraz Slezský Výmar. Za zmínku stojí též na čtyři desítky knih vášnivého sběratele Ignáce Dominika hraběte Chorinského z Ledské (1729-1792), jehož zámek Velké Hoštice se stal proslulým centrem kulturního a společenského života. Věhlasná byla především místní kapela, kterou vedl barokní skladatel Josef Puschmann (1738-1794).
Vedle těchto zmíněných knihoven existují záznamy i o dalších zámeckých fondech, které však na své objevení teprve čekají. Jedná se o zámecké knihovny Bernartice, Brantice, Dobroslavice, Dolní (Stará) Červená Voda, Fulštejn, Hlavnice, Horní Heřmanice, Jezdkovice, Jindřichov, Kravaře, Linhartovy, Petříkovy, Poruba, Raduň, Slezské Rudoltice, Šenov, Velké Heraltice, Velké Kunětice a Vlčice.

Velkým otazníkem a možno říct i příslibem dalších nálezů jsou tak historické fondy nejrůznějších slezských institucí. Předběžná komunikace proběhla např́iklad se Zemským archivem v Opavě či Muzeem Beskyd Frýdek-Místek a již dnes je známo, že se $\mathrm{v}$ jejich fondech exempláře pocházející ze slezských zámeckých knihoven nacházejí. Výstavu lze tedy chápat jako výzvu či lépe řečeno jako prosbu o budoucí spolupráci na cestě znovuobjevení pokladů slezských zámeckých biblioték a o jejich částečnou rehabilitaci.

\section{Barbora Nebeská \\ Knihovna Národního muzea \\ oddělení zámeckých knihoven \\ Václavské náměstí 68 \\ 11000 Praha 1}

4 Torza těchto knihoven se nachází na zámku Raduň, kde se historický knižní fond nedochoval. 